\title{
Phytochemical screening and antibacterial activity of dried pods of Prosopis Africana
}

\begin{abstract}
Baturh Yarkwan
Biochemistry Unit, Department of Biological Sciences, College of Science, Federal University of Agriculture, Makurdi, Benue State, Nigeria.

Received 2 July, 2015; Accepted 15 May, 2020

Evolving resistant microbial strains have posed a great challenge on antibacterial chemotherapy in recent times. Search for novel antimicrobial agents has therefore remained a highly prospective area of research, especially those of plant origin. To this end, Prosopis africana pod used in West Africa in traditional medicine was evaluated for phytochemical constituents using standard procedures. Antibacterial activity was determined using the disc diffusion method of National Committee for Clinical Laboratory Standards. Discs were impregnated with 0.10 and $0.20 \mathrm{mg} / \mathrm{ml}$ of the aqueous and ethanolic extracts. Test organisms were wild strains of Streptococcus pyogenes, Staphylococcus aureus, Salmonella typhi, Proteus mirabilis and Escherichia coli sourced from a medical hospital's microbiology laboratory. $0.20 \mathrm{mg} / \mathrm{ml}$ ethanolic fraction exhibited highest activity against $E$. coli and $S$. aureus with mean zone of inhibition of 18.2 and $17.6 \mathrm{~mm}$ respectively. The $0.20 \mathrm{mg} / \mathrm{ml}$ aqueous fraction was more active against $S$. aureus $(16.40 \mathrm{~mm})$ and $P$. mirabilis $(14.80 \mathrm{~mm})$. The least zone of inhibition was $10.10 \mathrm{~mm}$. Phytochemical screening of the extracts showed the presence of terpenoids, saponnins, glycosides, alkaloids and tannins, to which the observed antibacterial activity could be attributed. The extracts are potent in vitro antibacterial preparations. With this prospect, this can be employed as starting material for the development of a novel antimicrobial agent.
\end{abstract}

Key words: Phytochemicals, antibacterial activity, Prosopis africana pod, ethanolic extracts, aqueous extracts.

\section{INTRODUCTION}

African mesquite (genus Prosopis) is represented by about 45 species of trees and shrubs native to Africa/Asia (Orwa et al., 2009). Prosopis africana belongs to the Fabaceae- Mimosoideae family (Kolapo et al., 2009) in the class Taub Leguminosae, sub-family Mimosoideae (Weber et al., 2008). The English name of $P$. africana is a matter of controversy as some people call it iron tree while others identify iron tree as a different tree but it is popularly known all over the world as mesquite. Due to the large numbers of species, however, most research reports use the scientific name to identify the particular species which is under study. $P$. africana (African mesquite) is native to the North, Central and West Africa where it is commonly called Ayan (Yoruba), Abusurij (Arabic), Kiriya (Hausa), Gbaaye (Tiv) and Okpehe (Idoma) (Agishi, 2010).

The ripe and dry pods of $P$. africana are dark brown, cylindrical (about $15 \mathrm{~cm}$ long and $3 \mathrm{~cm}$ in diameter)

\section{E-mail: baturybatur@yahoo.com.}

Author(s) agree that this article remain permanently open access under the terms of the Creative Commons Attribution License 4.0 International License 
compartmented, thick, hard and shiny with woody walls (Orwa et al., 2009). There are about 10 loose, rattling seeds per pod with a thin, inter-marginal line around. Extraction of the seed from the hard pod is usually done by crushing. The bi-pinnate leaves are arranged along a pinnae of about 7-15 cm long with 2-4 pairs of opposite pinnae and 6-12 pairs of opposite leaflets per pinnae. Between the bases of each pair of pinnae is a fleshy pore-like gland. The leaflets are $1.5-4.0 \mathrm{~cm}$ long and $0.5-1.5 \mathrm{~cm}$ wide, with an apiculate apex and a rounded base (Orwa et al., 2009). Towards the end of the growth season thick and brush-like spikes are produced on new growing branches. The inflorescence comprises a solitary spike, set at the base of a leaf. The spike is pedunculate, $4-6 \mathrm{~cm}$ long and $1.5 \mathrm{~cm}$ in diameter (Weber et al., 2008; Orwa et al., 2009).

Different parts of the tree have been successfully used for the management of an array of ailments such as bronchitis, dermatitis, gonorrhoea, dysentery, malaria, rheumatism, sore throat, fevers, stomach cramps, skin diseases, headache, toothache, and as a dressing for wounds or cuts (Kolapo et al., 2009; Orwa et al., 2009; Nnamani et al., 2012). The leaves are used for the treatment of headache, toothache, as well as other related ailments (Kolapo et al., 2009). Freshly budding leaves and shoots are used as fodder, while cattle enjoy feeding on the pods (Ajiboye et al., 2013). The wood has a high thermal value of about $1720 \mathrm{Jkg}^{-1}$ and produces excellent charcoal and firewood (Orwa et al., 2009) making it a good source of fuel to the detriment of conservation ethics. The bark and root, rich in tannin is useful as a dyestuff (Ajiboye et al., 2013) and the pod ashes are a source of potash for making local soap used to treat skin disease, fevers and as eyewashes (Orwa et al., 2009). They contain 31-89\% tannin, depending on the part of the plant (Kolapo et al., 2009, Nnamani et al., 2012). The rich protein seeds are a very important condiment in soups and other dishes and it is used as human and animal feed (Adamu et al., 2011). Mineral elements composition showed phosphorus, potassium, sodium, magnesium and calcium are the major constituents, comprising 196, 617, 110, 420 and 362 $\mathrm{mg} / \mathrm{ml}$ respectively (Ajiboye et al., 2013) which suggest that consumption of the seed or its products could contribute substantially to the overall daily intake of these elements. The pod of $P$. africana contains about: $9.6 \%$ protein, $3 \%$ fat and $53 \%$ carbohydrate (Barminas et al., 1998; FAO, 2003, Nnamani et al., 2012; Ajiboye et al., 2013).

Various chemicals such as alkaloids, tannins, saponnins, cyanoglycosides, terpenoids, oleic and stearic acids which are often found naturally in plants have been implicated as being responsible for the antimicrobial activities of plants containing them (Cowan, 1999; Osbourn, 1996). Literature abound on the use of stem, roots and leaves of $P$. africana to effect cure to several ailments (Kolapo et al., 2009; Orwa et al., 2009; Agboola,
2004), but little work, if any at all has been reported over the antibacterial properties of the pods using aqueous and ethanolic extracts. Potash from the pods of this plant is reported to be used among folkloric medical practitioners to treat a range of ailments. Therefore, the objectives of this study are to identify the phytochemical constituents present in the aqueous and ethanolic extracts of the pods and testing its antibacterial activity against a range of common pathogenic bacteria isolates.

\section{MATERIALS AND METHODOLOGY}

\section{Collection of dried unripe pods}

Matured pods of identified $P$. africana that dropped by themselves were picked from the ground under the trees during the months of March and April, in Jaki, Shangev-ya, Kwande Local Government Area of Benue State and crushed to separate the seeds from the pods. This was done in keeping with the local practice of crushing to obtain the seeds. The crushed pods were transported to the laboratory at the Department of Biological Sciences, Federal University of Agriculture, Makurdi, Benue State; they were pulverized using porcelain mortar and pestle into fine powder and sieved through a fine nylon mesh clothe to obtain the fine powder which was kept dry and later used for the extraction.

\section{Preparation of extracts}

A $50 \mathrm{~g}$ mass of the ground sample was suspended in $300 \mathrm{ml}$ of $100 \%$ distilled water and $99 \%$ ethanol on a shaker (Stuart Scientific Orbital Shaker, Essex, UK) for $48 \mathrm{~h}$ at room temperature. The extract was filtered using a sterilized Buchner funnel and Whatman No. 1 filter papers. The filtrates were concentrated by drying in a water bath maintained at a temperature of $45^{\circ} \mathrm{C}$ until a brownish black residue was obtained. The extracts were removed, weighed and kept sealed in containers at refrigerated temperatures between $2-4^{\circ} \mathrm{C}$, from which aliquots were reconstituted for the experiment. Ethanolic extracts were prepared in a similar manner except that the solvent was $99 \%$ ethanol.

\section{Qualitative analysis of phytochemical constituents}

Qualitative phytochemicals screening was carried out according to Trease and Evans (1996), and briefly explained below.

\section{Test for tannins}

About $0.5 \mathrm{~g}$ of both aqueous and ethanolic extract was boiled in 20 $\mathrm{ml}$ of water in a test tube and then filtered. A few drops of $0.1 \%$ ferric chloride were added and observed for brownish green or a blue-black colouration which showed the presence of tannins.

\section{Test for saponins}

Two grams of both aqueous and ethanolic extract of pod was boiled together with $20 \mathrm{ml}$ of distilled water in a water bath and filtered. 10 $\mathrm{ml}$ of the filtrate was mixed with $5 \mathrm{ml}$ of distilled water in a test tube and shaken vigorously to obtain a stable persistent froth. The frothing was then mixed with 3 drops of olive oil. The appearance of emulsion was indicative of the presence of saponins. 


\section{Test for phlobatannins}

Two grams of both aqueous and ethanolic extract of the pod was boiled with $1 \%$ hydrochloric acid in a test tube. The deposition of a red precipitate indicates the presence of phlobatannins, which is characteristic of phlobaphene.

\section{Test for alkaloids}

One-gram portion each of aqueous and ethanolic extract was stirred with $5 \mathrm{ml}$ of $1 \%$ diluted hydrochloric acid on a steam bath and filtered. Then $1 \mathrm{ml}$ of the filtrate was treated with a few drops of Mayer's reagent and another $1 \mathrm{ml}$ portion similarly treated with Wagner's reagent. The formation of cream or pale yellow precipitate was observed indicating the presence of alkaloids.

\section{Test for steroids}

Acetic anhydride was added at $2 \mathrm{ml}$ to $0.5 \mathrm{~g}$ aqueous and ethanolic extract with $2 \mathrm{ml}$ sulphuric acid. Colour change from violet to blue or green indicates the presence of steroids.

\section{Test for glycosides}

Concentrated sulphuric acid was transferred at $1 \mathrm{ml}$ in a test tube. 5 $\mathrm{ml}$ of aqueous and ethanolic extract each was mixed with $2 \mathrm{ml}$ of glacial acetic acid containing 1 drop of ferric chloride. The mixture was carefully added to $1 \mathrm{ml}$ of concentrated sulphuric acid so that the concentrated sulphuric acid was underneath the mixture. The appearance of a brownish ring indicates the presence of cardiac glycoside fraction.

\section{Test for flavonoids}

A portion of both aqueous and ethanolic extracts, $0.5 \mathrm{~g}$ was heated with $10 \mathrm{ml}$ of ethyl acetate over steam bath for $3 \mathrm{~min}$. The mixture was shaken with $1 \mathrm{ml}$ of dilute ammonia solution. A yellow colouration was observed, indicating the presence of flavonoids.

\section{Test for terpenoids (Salkowski test)}

Five grams of aqueous and ethanolic extract was mixed in $2 \mathrm{ml}$ of chloroform in a test tube and $3 \mathrm{ml}$ of concentrated sulphuric acid was carefully added to form a layer. A reddish brown colouration at the interface was formed to show positive results for the presence of terpenoids.

\section{Collection of test organisms}

Already identified and characterized bacterial pathogens namely Streptococcus pyogenes, Staphylococcus aureus (gram positive), Escherichia coli, Salmonella typhi and Proteus mirabilis (gram negative) isolates were sourced from Bishop Murray Hospital Medical Microbiology Diagnostic Laboratory, Makurdi, Benue State, Nigeria. The isolates were identified following the methods of Cheesebrough (2000).

\section{Sensitivity test}

Circular discs were cut out from Whatman No.1 filter paper. The discs were boiled in distilled water for an hour to remove any preservative, which may contain antibacterial substances. The boiled discs were transferred to aluminum foil and oven dried at $100^{\circ} \mathrm{C}$. They were wrapped well in a foil and sterilized by autoclaving at $121^{\circ} \mathrm{C}$ for $15 \mathrm{~min}$ at $15 \mathrm{psi}$. The sterile discs were used for the tests according to Uchechi and Oghenerobo (2010).

\section{Test on bacterial sensitivity extract}

The disc diffusion technique according to Cheesebrough (2000) was employed. Briefly, a culture of each test bacteria was prepared, using the spread plate technique described by Pelczar and Chan (1977). A loopful of the inoculum was aseptically collected from a pure culture plate of each test bacterium and placed on the surface of sterile agar plate. A glass rod sterilized over blue flame and allowed to cool in air was used in spreading the inoculum evenly over the surface of the plate. Then very carefully, the extract embedded paper discs were picked with sterile forceps and placed in already marked quadrants on the plates. The plates were allowed to stand for a few minutes to enable the extract to diffuse into the medium and also for the discs to become firmly fixed on the culture surface, and thereafter, were incubated at $37^{\circ} \mathrm{C}$ in an incubator for $24 \mathrm{~h}$. They were observed for growth and the presence of inhibition zones as a sign of sensitivity to the test extract was noted. Extent of sensitivity was determined by the inhibition zone diameters as measured with a transparent $1 / 4$ - meter rule.

\section{Determination of extract yield}

The amount of extract obtained from each of the test solvents (water and ethanol) was determined gravimetrically. The total weight of the extract was obtained by evaporating the extract to dryness in a weighed evaporation dish. Subsequently, the dish and its content were reweighed. By difference, the weight of extract was calculated using the formula below:

Extract yield in $\mathrm{mg} / \mathrm{g}=\frac{W 2-W 1}{\text { Weight of the Sample }} \times \frac{1000}{1}$

w1 = weight of empty evaporation dish

w2 = weight of dish + extract

The weight of extract $\left(w_{2}-w_{1}\right)$ was multiplied by 1000 to convert it from grams to milligrams (Uchechi and Oghenerobo, 2010).

\section{Reconstitution of extract}

To facilitate the process of conducting the extract into the sterile diffusion discs and to be able to estimate an approximate concentration of the extract used per disc, the dry extract was reconstituted in minimum volume of sterile distilled water. 1 and $2 \mathrm{~g}$ of aqueous and ethanolic extract respectively were mixed with 10 $\mathrm{ml}$ of sterile distilled water and stirred with a glass rod till a uniform mixture was formed. The sterile discs were counted into the mixture and with the aid of sterile forceps the discs were mixed well with the reconstituted extract until the disc absorbed all the extracts. More sterile discs were added until the extract was used up. The approximate concentration of the extract on each paper discs was calculated using the formula adapted from Uchechi and Oghenerobo (2010).

\section{RESULTS AND DISCUSSION}

The phytochemical screening of the aqueous and ethanolic extracts showed the presence of saponin, tannin, 
Table 1. Qualitative phytochemical analysis of aqueous and ethanolic extracts of pods of $P$. africana.

\begin{tabular}{lcc}
\hline \multirow{2}{*}{ Plant Constituent } & \multicolumn{2}{c}{ Pod of $\boldsymbol{P}$. africana } \\
\cline { 2 - 4 } & Aqueous extract & Ethanolic extract \\
\hline Alkaloids & + & + \\
Tannins & + & + \\
Flavonoids & - & - \\
Saponins & + & + \\
Terpenoids & + & + \\
Phlobatannins & - & + \\
Glycoside & + & + \\
\hline
\end{tabular}

+ , Present, -, Absent.

Table 2. Inhibition of $E$. coli by both aqueous and ethanolic extract of pods of $P$. africana.

\begin{tabular}{|c|c|c|c|c|c|c|}
\hline \multirow{3}{*}{$\begin{array}{c}\text { Serial dilution of } \\
\text { bacterial }\end{array}$} & \multicolumn{6}{|c|}{ Zone of growth inhibition (mm) } \\
\hline & \multicolumn{2}{|c|}{ Aqueous } & \multicolumn{2}{|c|}{ Ethanol } & \multicolumn{2}{|c|}{ Standard Antibiotics } \\
\hline & $0.10 \mathrm{~g} / \mathrm{ml}$ & $0.20 \mathrm{~g} / \mathrm{ml}$ & $0.10 \mathrm{~g} / \mathrm{ml}$ & $0.20 \mathrm{~g} / \mathrm{ml}$ & Septrin $30 \mu g$ & Chloramphenicol $30 \mu \mathrm{g}$ \\
\hline $10^{-1}$ & 10.30 & 12 & 12 & 13 & 18 & 19 \\
\hline $10^{-2}$ & 10.50 & 11 & 14 & 17 & 16 & 16 \\
\hline $10^{-3}$ & 0 & 11 & 15 & 17 & 16 & 16 \\
\hline $10^{-4}$ & 0 & 0 & 20 & 22 & 15 & 16 \\
\hline
\end{tabular}

Table 3. Inhibition of $P$. mirabilis by aqueous and ethanolic extract of pod of $P$. africana.

\begin{tabular}{c|cc|cc|cc}
\hline \multirow{2}{*}{$\begin{array}{c}\text { Serial dilution } \\
\text { of bacterial }\end{array}$} & \multicolumn{6}{c}{ Zone of inhibition of growth (mm) } \\
\cline { 2 - 7 } & \multicolumn{2}{|c|}{ Aqueous } & \multicolumn{2}{c}{ Ethanol } & \multicolumn{2}{c}{ Standard antibiotics } \\
\cline { 2 - 7 } & $\mathbf{0 . 1 0} \mathbf{~} / \mathbf{m l}$ & $\mathbf{0 . 2 0} \mathbf{~ g / m l}$ & $\mathbf{0 . 1 0} \mathbf{~ g / m l}$ & $\mathbf{0 . 2 0} \mathbf{~ g / m l}$ & Septrin $\mathbf{3 0} \boldsymbol{\mu g}$ & Chloramphenicol 30 $\boldsymbol{\mu g}$ \\
\hline $10^{-1}$ & 12 & 13 & 12 & 14 & 14 & 19 \\
$10^{-2}$ & 0 & 14 & 15 & 17 & $\mathrm{NT}^{*}$ & $\mathrm{NT}^{*}$ \\
$10^{-3}$ & 13 & 17 & 16 & 19 & 15 & $\mathrm{NT}^{*}$ \\
$10^{-4}$ & 14 & 15 & 16 & 20 & 15 & $\mathrm{NT}^{*}$ \\
$10^{-5}$ & 16 & 15 & 14 & 17 & 15 & 16 \\
\hline
\end{tabular}

glycosides, terpenoid, alkaloids, flavonoids while phlobatannins was found only in the ethanolic extract (Table 1), but steroids were not detected in both extracts. Similar constituents were reported from the methanolic extracts of $P$. africana pods, according to Ajiboye et al. (2013). Alkaloids, steroids, phenols, tannins, and saponnins were identified in the roots and stem of $P$. africana, while cyanoglycosides were not detected in the stem but found in the roots (Kolapo et al., 2009) and Bosha and Asuzu (2015) also reported similar phytochemicals in varying quantities. These groups of plant chemicals are thought to constitute the active ingredients exhibiting antibacterial activity against the tested microbial isolates (Cowan, 1999), proving why the pods are popularly used as remedies against many bacteria diseases in folkloric medical practice in West
African states.

The antibacterial activity of the aqueous and ethanolic extracts of the pods on the five test pathogenic wild strains of bacteria (E. coli, S. typhi, P. mirabilis, $S$. aureus, $S$. pyogenes) are as shown in Tables 2 to 6 . Both water and ethanolic extracts were found to possess antibacterial activity and affected the test organism to varying degrees. This could be due to difference in polarity strength of solvents which is perhaps responsible for the difference in solubility of the plant active phytochemicals, as also reported by Abubakar et al. (2011). Thus, the concentration of the active ingredients in the solvents is thought to vary, besides the fact that phlobatannins were not detected in the aqueous extract but present in the ethanolic extract.

Aqueous extract inhibited the gram-negative pathogen 
Table 4. Inhibition of $S$. typhi by the aqueous and ethanolic extracts of pod of $P$. africana.

\begin{tabular}{|c|c|c|c|c|c|c|}
\hline \multirow{3}{*}{$\begin{array}{l}\text { Serial dilution of } \\
\text { bacterial }\end{array}$} & \multicolumn{6}{|c|}{ Zone of inhibition of growth $(\mathrm{mm})$} \\
\hline & \multicolumn{2}{|c|}{ Aqueous } & \multicolumn{2}{|c|}{ Ethanol } & \multicolumn{2}{|c|}{ Standard antibiotics } \\
\hline & $0.10 \mathrm{~g} / \mathrm{ml}$ & $0.20 \mathrm{~g} / \mathrm{ml}$ & $0.10 \mathrm{~g} / \mathrm{ml}$ & $0.20 \mathrm{~g} / \mathrm{ml}$ & Septrin $30 \mu \mathrm{g}$ & Chloramphenicol $30 \mu \mathrm{g}$ \\
\hline $10^{-1}$ & 10.10 & 10.20 & 13 & 14 & 12 & 13 \\
\hline $10^{-2}$ & 11 & 12 & 13 & 15 & 11 & 18 \\
\hline $10^{-3}$ & 13 & 14 & 10.10 & 15 & 11 & NO* \\
\hline $10^{-4}$ & 15 & 14 & 14 & 16 & $\mathrm{NT}^{*}$ & $N T^{*}$ \\
\hline $10^{-5}$ & 15 & 15 & 11 & 17 & 20 & 20 \\
\hline
\end{tabular}

${ }^{*} \mathrm{NT}=$ Not Tested; NO = Not observed.

Table 5. Inhibition of $S$. pyrogenes by both aqueous and ethanolic extract of pods of $P$. Africana.

\begin{tabular}{c|cccccc}
\hline \multirow{2}{*}{$\begin{array}{c}\text { Serial dilution of } \\
\text { bacterial }\end{array}$} & \multicolumn{6}{|c}{ Zone of inhibition of growth (mm) } \\
\cline { 2 - 7 } & \multicolumn{2}{|c}{ Aqueous } & \multicolumn{2}{c}{ Ethanol } & \multicolumn{2}{c}{ Standard Antibiotics } \\
\cline { 2 - 7 } & $\mathbf{0 . 1 0} \mathbf{~} / \mathbf{m l}$ & $\mathbf{0 . 2 0} \mathbf{~} / \mathbf{m l}$ & $\mathbf{0 . 1 0} \mathbf{~} / \mathbf{m l}$ & $\mathbf{0 . 2 0 ~} \mathbf{~} / \mathbf{m l}$ & Septrin $\mathbf{3 0} \boldsymbol{\mu g}$ & Chloramphenicol $\mathbf{3 0} \boldsymbol{\mu g}$ \\
\hline $10^{-1}$ & 0 & 0 & 11 & 12 & 17 & 16 \\
$10^{-2}$ & 0 & 12 & 12 & 14 & NO* & 17 \\
$10^{-3}$ & 14 & 15 & 16 & 19 & 16 & 17 \\
$10^{-4}$ & 12 & 13 & 18 & 20 & 14 & 18 \\
$10^{-5}$ & 10.10 & 14 & 19 & 20 & 17 & 22 \\
\hline
\end{tabular}

NO $=$ Not observed

Table 6. Inhibition of $S$. aureus by both aqueous and ethanolic extract of pod of $P$. Africana.

\begin{tabular}{|c|c|c|c|c|c|c|}
\hline \multirow{3}{*}{$\begin{array}{l}\text { Serial dilution } \\
\text { of bacterial }\end{array}$} & \multicolumn{6}{|c|}{ Zone of inhibition of growth $(\mathrm{mm})$} \\
\hline & \multicolumn{2}{|c|}{ Aqueous } & \multicolumn{2}{|c|}{ Ethanol } & \multicolumn{2}{|c|}{ Standard Antibiotics } \\
\hline & $0.10 \mathrm{~g} / \mathrm{ml}$ & $0.20 \mathrm{~g} / \mathrm{ml}$ & $0.10 \mathrm{~g} / \mathrm{ml}$ & $0.20 \mathrm{~g} / \mathrm{ml}$ & Septrin $30 \mu \mathrm{g}$ & Chloramphenicol $30 \mu \mathrm{g}$ \\
\hline $10^{-1}$ & 11 & 12 & 12 & 13 & 20 & 20 \\
\hline $10^{-2}$ & 14 & 15 & 16 & 17 & 16 & 20 \\
\hline $10^{-3}$ & 16 & 17 & 18 & 19 & 20 & 20 \\
\hline $10^{-4}$ & 19 & 18 & 18 & 19 & 20 & 20 \\
\hline $10^{-5}$ & 20 & 20 & 21 & 22 & 18 & 20 \\
\hline
\end{tabular}

E. coli (Table 2), to diameter of $10.30 \mathrm{~mm}, 12 \mathrm{~mm}$ at a concentration of $0.10 \mathrm{~g} / \mathrm{ml}$ and $12,13 \mathrm{~mm}$ at a concentration of $0.20 \mathrm{~g} / \mathrm{ml}$ both at serial dilution of $10^{-1}$ for aqueous and ethanolic extracts respectively. Ethanolic extracts at $0.2 \mathrm{mg} / \mathrm{ml}$ showed a zone of inhibition of 21 and $22 \mathrm{~mm}$ for $E$. coli serial dilution of $10^{-5}$. With decreasing bacteria concentrations, wider zones of inhibition were observed for all extracts and concentrations tested. The aqueous extract at a concentration of 0.10 and $0.20 \mathrm{~g} / \mathrm{ml}$ had a higher inhibition zone on $E$. coli than the $0.10 \mathrm{~g} / \mathrm{ml}$ disc. This could be due to their phytochemical concentration difference in the two discs. Also comparing the zone of aqueous extract at both 0.10 and $0.20 \mathrm{~g} / \mathrm{ml}$ to that of ethanolic extract, there was higher inhibition zone expressed by ethanolic discs on the pathogens than the aqueous discs. This could be due to varying concentrations of the active ingredients in the solvents, and consequently in the discs as previously reported (Ajiboye et al., 2013; Osbourn et al., 1996).

The zone of inhibition obtained from the ethanolic extract disc tends to be higher at 0.10 and $0.20 \mathrm{~g} / \mathrm{ml}$ especially at $10^{-5}$ serial dilution, than the standard antibiotics discs Septrin $(30 \mu \mathrm{g})$ and Chloramphenicol (10 $\mu \mathrm{g})$ used as the positive control. This shows that the phytochemical constituents of pods of $P$. africana have appreciably high antibacterial activity. However, the positive controls both showed a higher inhibitory activity 
at the lower dilutions where test organisms were more concentrated in the culture plate. This implies the pathogen was susceptible to the drugs and could be a viable treatment option for administration to infected patients.

Aqueous extract inhibited the gram-negative pathogen, Proteus mirabilis (Table 4), to diameter of $12 \mathrm{~mm}$ each, at concentration of $0.10 \mathrm{~g} / \mathrm{ml}$ and $13 \mathrm{~mm}, 14 \mathrm{~mm}$ concentration of $0.20 \mathrm{~g} / \mathrm{ml}$ both at serial dilution of $10^{-1}$ for aqueous and ethanolic extracts respectively. At $10^{-5}$, a zone of inhibition of 16 and $14 \mathrm{~mm}$ for aqueous extract, and 15 and $17 \mathrm{~mm}$ was observed for Proteus mirabilis. Considering the aqueous extract at a concentration of 0.10 and $0.20 \mathrm{~g} / \mathrm{ml}$, the latter has a higher zone of inhibition on $P$. mirabilis than $0.10 \mathrm{~g} / \mathrm{ml}$ concentration of the extract, due to the active ingredient's concentration in the extracts. The bacterium was more susceptible to ethanolic extract than the aqueous extract. Ethanolic extracts discs showed higher zone of inhibition at 0.20 $\mathrm{g} / \mathrm{ml}$, at serial dilution of $10^{-1}$ to $10^{-5}$ than the standard antibiotics discs of Septrin $(30 \mu \mathrm{g})$ and Chloramphenicol $(10 \mu \mathrm{g})$. This shows that the phytochemical constituent of pods of $P$. africana have high antibacterial activity against the organism. $P$. mirabilis is a pathogenic gram-negative bacterium, frequently implicated in urinary tract infections in both genders (Rubin et al., 1986) and associated complications.

Aqueous extract inhibited the gram-negative pathogen, S. typhi (Table 4) to different extents as shown by the respective zones of inhibition against dilutions. Considering the aqueous extract concentrations, $0.2 \mathrm{~g} / \mathrm{ml}$ tends to have a higher zone of inhibition on $S$. typhi than $0.10 \mathrm{~g} / \mathrm{ml}$. The ethanolic extract has a higher zone of inhibition than the aqueous extract. This shows ethanol to be a better solvent for extracting the active ingredients effective against $S$. typhi than water. Ethanolic extracts discs' zone of inhibition $(14 \mathrm{~mm})$ tends to be higher at $0.20 \mathrm{~g} / \mathrm{ml}$, serial dilution of $10^{-1}$ than the standard antibiotics discs of Septrin $(30 \mu \mathrm{g})$ and Chloramphenicol $(10 \mu \mathrm{g})$ which had 12 and $13 \mathrm{~mm}$ respectively. This shows the phytochemical constituent of pods of $P$. africana at the respective test concentrations to have higher antibacterial activity against $S$. typhi.

Aqueous extract inhibited the gram-positive pathogen, S. pyogenes (Table 5). The aqueous extract at 0.10 and $0.20 \mathrm{mg} / \mathrm{ml}$ with bacterial concentration at $10^{-1}$ showed no inhibitory activity. The highest inhibition was observed at $10^{-3}$ serial dilution. Ethanolic extract discs showed an increasing activity, climaxing at $19 \mathrm{~mm}$ for $0.10 \mathrm{mg} / \mathrm{ml}$ at $10^{-5}$ serial dilution. The discs with $0.20 \mathrm{mg} / \mathrm{ml}$ showed highest zone of inhibition of $20 \mathrm{~mm}$ at $10^{-4}$ serial dilution, which was sustained at the $10^{-5}$ dilution. This indicates susceptibility of the organism against the active ingredients contained in extracts of $P$. Africana. The varying extent of inhibition is due to the extent of solubility of the active ingredients in the solvent, and the quantity of the active ingredients available against the concentration of organisms. Ethanolic extracts' disc zone of inhibition tends to be higher at $0.20 \mathrm{~g} / \mathrm{ml}$ especially at serial dilution of $10^{-3}$ and $10^{-4}$ than the standard antibiotics discs of Chloramphenicol $(30 \mu \mathrm{g})$ and Septrin, $(30 \mu \mathrm{g})$. This shows a higher antimicrobial activity of the $0.20 \mathrm{mg} / \mathrm{ml}$ extract discs than that from the standard drugs.

Extracts of $P$. africana pods inhibited the Gram-positive pathogen, $S$. aureus, at varying degrees (Table 6). Both concentrations of the aqueous extracts showed an increasing zone of inhibition for all the increasing dilutions of microbial culture plates tested. Ethanolic extracts discs' zone of inhibition tends to be higher at $0.20 \mathrm{~g} / \mathrm{ml}$ especially at serial dilution of $10^{-5}$, which was even higher than the 18 and $20 \mathrm{~mm}$ obtained for standard discs of Septrin $(30 \mu \mathrm{g})$ and Chloramphenicol $(30 \mu \mathrm{g})$ respectively, proving the therapeutic potential of the extracts against infections caused by the pathogen.

Generally, it could be observed the higher discs concentrations of $20 \mathrm{mg} / \mathrm{ml}$ showed higher inhibitory activities than the lower concentrations of $10 \mathrm{mg} / \mathrm{ml}$, across the tested samples. Moreover, discs soaked in the ethanolic extracts showed higher inhibitory activities than those from the aqueous extracts. This shows the organic solvent ethanol is better in extracting the antibacterial active ingredients in $P$. africana pods than water. Ajiboye et al. (2013) showed $25 \mathrm{mg} / \mathrm{ml}$ coated methanolic extract discs of $P$. africana pods exhibited antibacterial activity showing zones of inhibition between $8-17 \mathrm{~mm}$ against an array of pathogenic microbes. This study has shown at $20 \mathrm{mg} / \mathrm{ml}$, the zone of inhibition of ethanolic extracts of pods is between $12-22 \mathrm{~mm}$, which is higher than that reported by the authors. Since methanol and ethanol are chemicals of the same homologous series, this might be due to the differences in the strain of microbes used or the extraction procedure or even the compositional differences of the pods used, since there were sourced from different geographical zones with climatic conditions and probably different soil nutritional status.

Phytochemical screening of the pods of $P$. africana reveals the presence of tannin, glycosides, saponin, terpeniod, alkaloids, flavonoids, phlobatannin but steroids were not detected. In most of the test cases at the specified conditions, ethanolic extracts showed greater antimicrobial activity than the aqueous extracts. This implies ethanol is a better solvent for the extraction of the active ingredients in the pods of $P$. africana than water. The zone of inhibition was more for $0.20 \mathrm{mg} / \mathrm{ml}$ than for $0.10 \mathrm{mg} / \mathrm{ml}$ and at higher dilutions. This implies that higher concentration than $0.20 \mathrm{mg} / \mathrm{ml}$ might be required to give the ethanolic extract higher activity against all the pathogens, even at very low dilutions.

All the test organisms, namely E. coli, S. typhi, $P$. mirabilis, $S$. aureus, $S$. pyogenes were shown to be susceptible to the active ingredients in the extracts. Since these organisms are both Gram-positive and Gramnegative organisms, it is likely that the mechanism of activity observed might not be linked with cell wall 
formation or disruption/interference with cell wall integrity. It is rather thought to be interfering with the protein synthesis apparatus of the organisms or obstructing key regulatory or metabolic enzymes. It could also be by hampering any other molecular process that is vital for the survival of the organism.

\section{CONCLUSION AND RECOMMENDATION}

Since most of these organisms are virulent, exhibiting varying degree of mutagenicity, thus evolving new resistant strains to established antibiotics. The empirically proven knowledge that the pods of $P$. africana contain active ingredients that possess antibacterial activity is a welcome development that should be harnessed towards the development of novel antibacterial agents. This can be achieved by identifying the exact antibacterial agent(s), elucidating the molecular formular, and highlighting the mechanism of action against the bacteria in order to establish the exact point of molecular effect on the organisms. Moreover, toxicity assay could be performed on the extracts in model animals to ascertain to what extent the body can tolerate the active ingredients in the extracts. Typhoid fever is a common ailment affecting rural dwellers. The use of potash from the pods of $P$. africana on soups, other dishes and locally made soaps, as it is the practice in some rural settlements in Nigeria, is hereby encouraged. This could help check the effect of the disease and bring cure to those already affected. Synergistic studies of the ethanolic extracts with other some antibiotics, especially against $S$. typhi should be investigated, considering the widespread menace of the organism in Nigeria.

\section{CONFLICT OF INTERESTS}

The author has not declared any conflict of interests.

\section{REFERENCES}

Abubakar B, Aliyu M, Mikhail S, Hamisu I, Adebayo O (2011). Phytochemical screening and antibacterial activities Of Vernonia Ambigua, Vernonia blumeoides and Vernonia oocephala (Asteraceae). Acta Poloniae Pharmaceutica ñ Drug Research 68(1):67-73.

Agishi EC (2010). Tiv, Idoma, Etulo, Igede, Akweya, Hausa, English and Scientific names of plants. Agitab Publishers. pp. 1-97

Adamu L, Igwebuike JU, Kwari ID, Aliyu J (2011). The effects of Prosopis africana pulp on nutrient digestibility, carcass components and blood composition of growing rabbit. Journal of Environmental Issues and Agriculture in Developing Countries 3(1):79-87.

Agboola DA (2004). Prosopis africana (Mimisaceae): Stem, roots, and seeds in the economy of the savanna areas of Nigeria. Economic Botany Supplement (Winter, 2004), pp. S34-S42.

Ajiboye AA, Agboola DA, Fadimu OY, Afolabi AO (2013). Antibacterial, phytochemical and proximate analysis of Prosopis africana (Linn) seed and pod extract. FUTA Journal of Research in Sciences 1:101109.
Barminas JT, Marina HM, Ali J (1998). Nutrient content of Prosopis africana seeds. Plant Foods for Human Nutrition 52(4):325-328.

Bosha JA, Asuzu IU (2015). Comparative studies of the pharmacological activities of Prosopis africana fruits and its fraction. Medicinal and Aromatic Plants Research Journal 3(1):1-8.

Cowan MM (1999). Plant Products as Antimicrobial Agents. Clinical Microbiology Reviews 12(4):564- 582.

Cheesebrough M (2000). Medical Laboratory Manual in Tropical Countries. Butterworth-Heineman Limited Oxford. pp. 370-380.

FAO (2003). Non-Wood Forest products and Nutrition. Food and Agricultural Organisation of the United Nations, Food and Nutrition Division Publication.

Kolapo AL, Okunade MB, Adejumobi JA, Ogundiya MO (2009). Phytochemical composition and antimicrobial activity of Prosopis africana against some selected oral pathogens. World Journal of Agricultural Science 5(1):90-93.

Nnamani PO, Kenechukwu FC, Chika OC, Otuu FC (2012). Performance of Prosopis africana pell powder (PAPP) as a novel sorbent for remediating malachite green contaminated aqua system. Scientific Research and Essays 7(48):4130-4137.

Pelczar MJ, Chan ECS (1977). Laboratory Exercise in Microbiology, McGraw- Hill Inc. USA, pp. 17, 301-303.

Rubin RH, Tolkoff-Rubin NE, Cotran RS (1986). In The Kidney. Brenner, B.M., Rector, F.C. Eds., W. B. Saunders Co, Philadelphia, pp. 1085-1141.

Trease K, Evans WC (1996). Pharmacognosy, 14th edn, Harcourt Brace and Company, PTE Itd, India, pp. 504-507.

Weber JC, Larwanou M, Abasse TA, Kallinganre A (2008). Growth and survival of Prosopis africana provenances tested in Niger and related rainfall gradients in the West African Sahel. Forest Ecology and Management 256(4):585-592.

Orwa C, Mutua A, Kindt R, Jamnadass R, Anthony S (2009). Agroforestree Database: $\mathrm{A}$ tree reference and selection guide version 4.0 http://www.worldagroforestry.org/sites/treedbs/treedatabases.asp)

Osbourn AE (1996). Preformed antimicrobial products chemistry. Phytochemstry 40:1585-1612.

Uchechi NE, Oghenerobo VE (2010). The antibacterial activity of crude leaf extract of Citrus sinensis (sweet orange). International Journal of Pharmacy and Biological Science 1:4. 